\title{
INTERCESSION AND SUCCESSION, ENLIGHTENMENT AND REFLECTION: THE INSCRIPTIONAL AND DECORATIVE PROGRAMME OF THE QARATAY MADRASA, KONYA עם
}

\author{
Scott Redford
}

This chapter addresses a traditional art-historical subject: a patron and a building. The patron in question is Jalal al-Din Qaratay, court emir and regent of the Seljuk sultanate between the years ca. I 249 and I254, a period when the Seljuk state was weak and the three sons for whom he served as regent were children. For all intents and purposes, during this time, Qaratay ruled the Seljuk sultanate. The building he commissioned during the period of his regency served both as a school for religious and legal sciences, or madrasa, and as his mausoleum. He built it in the Seljuk capital of Konya around the year I 25 I. Known as the Qaratay Madrasa, this building is located at the base of the citadel hill in the centre of the city. Throughout the building, inscriptions, presented in a variety of forms, play a significant role. ${ }^{\mathrm{I}}$

Contemporaneous historical and religious sources report that Qaratay was a very pious Muslim, with his piety taking a mystic and ascetic bent. They record that he was well known to another Jalal al-Din living in Konya at the time: his younger contemporary Jalal al-Din Rumi, Sufi founder of the Mawlawiyya/Mevlevi dervish order, popularly called the Whirling Dervishes. As an index of his asceticism, two contemporaneous historical sources note that Qaratay forswore eating meat, drinking wine and engaging in sexual intercourse. One source also notes that literate and illiterate, Muslim and non-Muslim, the orphaned and the widowed, but especially Sufis and all manner of religious men from far and wide, sought him out and benefitted from his generosity. ${ }^{2}$

In the foundation document of his madrasa, as well as that of the large caravanserai that he endowed in the previous decade, Qaratay prescribes that in place of oil lamps, which were the normal means of lighting in these (and other 
contemporaneous) buildings, candles be lit in certain places and at certain times. According to the instructions in these documents, candles were to burn in the mosque of the caravanserai all year long - before, during and after prayer times at dusk and dawn and in the madrasa on three holy nights: those celebrating the revelation of the Qur'an, the conception of the Prophet and the descent of the Qur'an. The foundation document of his caravanserai also prescribes that all comers, Muslim or non-Muslim, free or slave, man or woman, be treated equally. ${ }^{3}$

The Seljuk historian Ibn Bibi states that Qaratay was himself of slave origin and from Anatolia; likely he was a Christian captured and converted to Islam at an early age. We know that Qaratay had two brothers, both of whom also had assumed Turco-Islamic names and served as high-ranking officials of the Seljuk sultanate. One of these, Kamal al-Din Rumtash, built his own madrasa, today in ruins, directly across the street from that of his brother. 4

In this chapter, I use inscriptional and other data from the Qaratay Madrasa to argue for the creation of spaces, constructed architecturally and socially, that recognised a continuum of religious practice between Christianity and Islam as valid. The placement of writing within these spaces also served to emphasise continuity. 5 In addition to a continuum in practice, in Islam there is a natural sense of succession or completion between Islam and the religions of other peoples of the book, one that is explored later in this chapter. Whether or not it related to the veneration of saints in Christianity, medieval Islamic mysticism had a particular interest in holy men, their sanctity and their relation to other divine powers. The rise in importance of the veneration of the Prophet Muhammad as al-insān al-kämil, the perfect man, a model for Muslims, coincided with the spread of the practice of night-time celebrations of such signal events as the beginning of the revelation of the Qur'an, the conception of Muhammad, the beginning of the dictation of the Qur'an to him and his night voyage into the heavens. The celebration of these sacred nights, a development of medieval Islamic practice relating in part to the self-identification of Sufi holy men with Muhammad, gained in importance at this time. Ibn Bibi reports that Qaratay's piety caused him to be granted the privilege of writing the title Vali Allāh fi'l-ard next to his signature on official Seljuk state documents. This term can be translated as 'God's friend on earth', but the term Vali also means holy man or saint in Sufism, as can be seen by its use in the foundation document of the madrasa. The prescription of celebration of these holy nights in the madrasa can be tied not only to Sunni Muslim practice at this time but also to a possible self-identification of the ascetic/mystic emir with the Prophet Muhammad himself. In this respect it is interesting to note that the name of the artist who copied and illustrated the eleventh-century Persian language romance of Varqeh and Gülshah at this time can be found among the list of the witnesses to the foundation document of the Qaratay Madrasa. This romance invokes the Prophet Muhammad on many occasions and ends with the revivification of the lovers by God as the result of prayers made by the Prophet Muhammad himself and taken to the heavens by the Angel Gabriel. ${ }^{6}$ 


\section{THE DECORATIVE AND EPIGRAPHIC PROGRAMME OF THE QARATAY MADRASA I: THE PORTAL}

This much biographical information is apposite to a chapter that argues for an intimate relationship between this patron and the artisans decorating the portal and the interior of the madrasa. Michael Meinecke has mustered stylistic evidence for the presence of a workshop of tile mosaic artisans working in Konya from the early I 23 Os to the I 25 os, linking the only signed work, the Sirçalı Madrasa (I $\left.24^{2}-3\right)$, with the mosaic tilework of the dome and mibra $\bar{b} b$ of the Alaeddin Mosque (which he dated to the early I 230s); this signed work was also linked to later buildings such as the madrasa of Qaratay's brother Kamal al-Din Rumtash ( $248-9$ ) and the Qaratay Madrasa itself (I $25 \mathrm{I}-3$ ), all built by members of the Seljuk elite in the capital city of the sultanate. A decades-long period of residency and acquaintanceship between artists and members of the Seljuk ruling class as the result of high-level patronage accords not only with the increasing technical sophistication of the tilework in these buildings but also the integration of tile technique with the decorative and epigraphic programme exhibited in the Qaratay Madrasa. ${ }^{7}$

The masons who worked on the marble inlay and inscriptions of the façade of the building (Fig. 45) are unknown, and there are no good candidates like that of Muhammad al-Tusi, who was proposed by Meinecke as the leader of the tile workshop. The majority of the scholarship dealing with the façade of the Qaratay Madrasa has been concerned principally with its relationship to the nearby Alaeddin Mosque, whose main entrance was furnished with a similar doorway and interlace marble decoration by an architect from Damascus in the early I 220 ; researchers have also examined problems with the foundation inscription of the building, which is located on the façade. ${ }^{8}$

Let us look instead at the religious inscriptions of the facade. An unusual Qur'anic quotation runs on either side of the entrance. It is executed in an elegant cursive script that does not aim for the monumentality of the foundation inscription, with its drawn-out hastae: rather, it is written in a style more reminiscent of a Qur'anic chapter heading. The quotation is from the Sura of the Ant, verse I9, which recounts the deeds of Solomon, a prophet in Islam. Solomon also held a special place in mystical Islam because of his esoteric knowledge, in this chapter the knowledge of the language of birds and insects. This verse introduces us to the concept of God granting prophets esoteric knowledge and, without identifying him by name, introduces Solomon (and indirectly, his father David, who is named in the previous verse).

The door frame of the Qaratay Madrasa copies the format of the door frame of the nearby central mosque of the Seljuk dynasty, the Alaeddin Mosque, but with modifications. Here, instead of the opening sura of the Qur'an, which is around the doorway of the Alaeddin Mosque, twenty-two short, simple badith (sayings of the Prophet Muhammad), written in easily legible cursive script, are carved into 


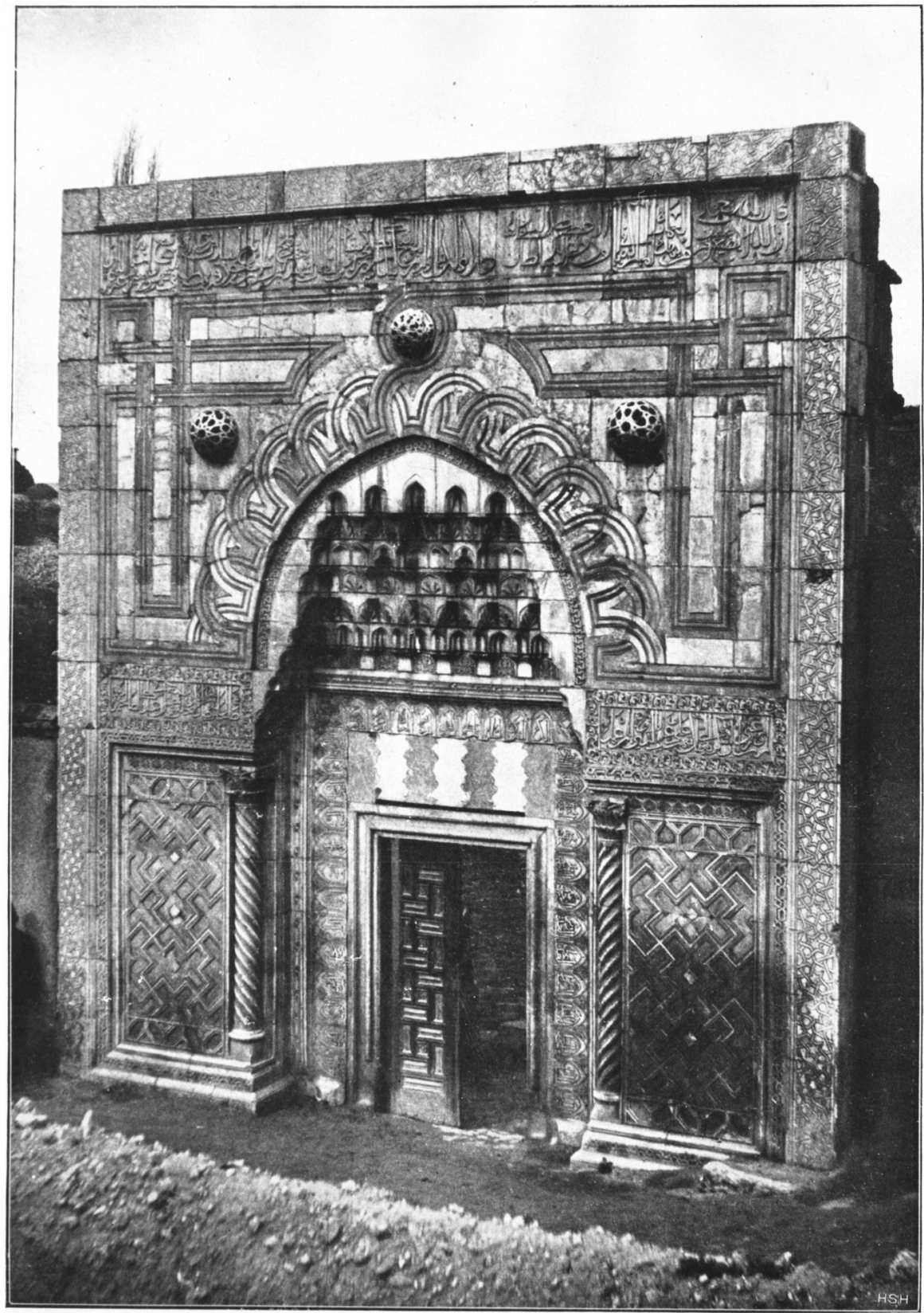

45. The portal of the Qaratay Madrasa at the beginning of the twentieth century. (After J. H. Löytved, Konia. Inschriften der seldschukischen Bauten (Berlin: J. Springer, I907), pl. 47)

the marble door frame, the sole entrance and exit of the building. These badith form the first part of the epigraphic programme of the madrasa that calls to mind the educational function of the building. The hadith chosen for inclusion here are all structured in the same very short, simple declarative sentences, appropriate 
for the level of understanding of students studying Islamic law and theology in Arabic, a language that was not likely to have been native to any of them. They are written in the individual cells, or leaves, of the vegetal design carved in the marble door surrounds.

These hadith, constituting pithy homilies with pedagogic intent, can be read separately or together as a text, with connections between individual ḅadith and, especially toward the end of the series, as a commentary connected with the founder. In this way, they, like other elements of the decorative programme of the madrasa, are capable of being understood separately, but also together, with connections and levels of meaning apprehended only after the kind of repeated exposure that goes with daily ingress and egress. The twenty-two badith are written within the thirty-seven cells of the design; several then span two cells, often eliminating the $w a$, or 'and' that links the two parts of the badith as written in hadith compendia, or other words.

Following the direction of writing of the Arabic script, the badith start at the lower right-hand corner and end at the lower left-hand corner. The badith on the right-hand side of the doorway largely concern moral precepts, with a certain emphasis on finance: they warn against indebtedness and emphasise group values. The hadith above the doorway continue in this vein, but also address matters of praxis - again aspects important to students. For instance, a sequence of three badith in the middle of this part of the frame can be thought of as having being grouped together for a purpose. The first of the three states that one should offer greetings before beginning conversation, al-salām qabl (al-)kalām. This is followed by a badith proclaiming that questioning is half of knowledge, al-su'al nisf al-'ilm, and one emphasising the importance of prayer for worship (inna) al-du'a buwa al-'ibāda. In this way the initiation of speech, the content of (educational) speech and the importance of speech (as part of prayer) for faith are all addressed, with a progression from the initiation of speech through its use to attain different levels of knowledge.

On the left-hand side, moral precepts dominate, with a return to the ' $\mathrm{x}$ is half of y' formulation quoted earlier. The longest badith found here introduces what I consider to be a biographical element relating to the founder, an element that continues until the end. This badith states that precaution is half of life, love is half of intelligence, and worry is half of old age: al-tadbir nisf al-'aysh (wa) al-tawaddud nisf al-'aql (wa) al-hamm nisf al-haram. After this come hadìth that describe good and bad actions in opposition. The first of these uses the word khayr, which means good, but also denotes good work(s): good is customary (and) evil is troublesome, al-khayr 'a da (wa) al-sharr lajāja. Coming after a ḥadīth mentioning old age, this hadith can be seen as containing a personal reference to Qaratay and the good work of his madrasa. The thirty-second and thirty-third cells contain another badith with a subject that, in the context of the other badith, is so unusual as to demand a biographical explanation. This badith states that a 
child is a cause of greed and cowardice, (inna) al-walad mabkbala majbana. Coming as it does after b adīth mentioning old age and pious works, this badìth may be connected to the political context of Qaratay's regency: the factions surrounding each of the three young brothers of the ruling dynasty in general and the debauched behaviour of the teenaged sultan 'Izz al-Din in particular. The string of hadīth ends with two that rhyme. The first of these once again contains ominous portents: foul language comes from harshness, al-badha') min al-jaf $\bar{a}$ ', whereas the final badith fittingly proclaims the superiority of the Muslim holy book: the Qur'an is the remedy, al-Qur'ān huwa al-dawä'. ${ }^{9}$

To summarize, the portal of the Qaratay Madrasa is a complex composition that reflects the close partnership of patron and craftsmen. A foundation inscription, something usually found over the door, lies near the top of the entire portal. Below the inscriptional band is a seemingly abstract composition of black-andwhite marble, but one whose shapes recall the angular writing conventionally called kufic. ${ }^{\text {IO }}$ A shallow muqarnas vault rises above the doorway. At the level of the base of this vault, the muqarnas is flanked by an unusual Qur'anic quotation, which itself runs across the façade just above the level of the top of the hadith surrounding the entranceway. The primary function of the hadith is pedagogical, but they also introduce the concept of an inscriptional text that can be read and understood separately, as well as a whole, and whose meaning reveals itself over time; they add a biographical element to religious inscriptions. The position of the hadith around a doorway also introduces the idea of passage, something also found in the interior of the building.

\section{THE DECORATIVE AND EPIGRAPHIC PROGRAMME OF THE QARATAY MADRASA II: THE DOMED COURTYARD}

Once through the portal doorway, a visitor would have immediately entered a domed, tiled vestibule. Unfortunately, the dome that once rose atop this space, one that connects the portal to the domed courtyard of the madrasa, has long since collapsed. At one time this dome was decorated with tile mosaic, several pieces of which are still in situ above the interior of the doorway and around one side of the entrance into the main domed space of the interior. From here, a doorway leads unobtrusively into a corner of the main space of the building, a courtyard topped by a large hemispheric dome. ${ }^{\text {II }}$

This dome once terminated in an oculus, now covered, that provided the principal source of light to the interior. There is a square pool in the middle of the courtyard, directly underneath the oculus. This central covered courtyard is surrounded by subsidiary spaces. To three sides were rooms that have collapsed over the centuries and been rebuilt. Judging from the number of doorways on these three sides, they must have led to the rooms that housed at least some of the 
students studying here. To the far side, opposite the entrance to the courtyard, is a raised vaulted hall, or îwān (Fig. 46). It is flanked by two doorways, both leading into domed rooms. This centralized building, with a dome hovering over the main space, is given direction by the iwwan at the back opposite the entrance, the main teaching space of the madrasa. At the back of this iwwan is a window, the second major source of lighting for the main space of the building. The domed tomb chamber of Qaratay himself is entered through a doorway to the left of this îwan.

The raised îwān opposite the entrance gives the building two foci, two directional axes. The eye is led to these two axes - the horizontal one leading to from east to the îwān to the west, and the vertical one leading to the dome both because of the concentration and variety of the tile mosaic patterns and inscriptions and because both axes culminate in the two main light sources for the building: the window at the back of the $\bar{i} w \bar{a} n$ and the oculus at the top of the dome.

The inscriptional and decorative programmes of the Qaratay Madrasa combine the pedagogical function of the space with the spiritual inclinations of the patron. This madrasa is justly famous for its tilework, which, in its opulence, abundance and variety, recalls a palace rather than a school. The contrasting modesty of the decoration of the tomb chamber, with its untiled dome, can be seen as an indirect acknowledgement of the funerary function of this space. To the abundance of tile and variety of tile technique can be added skill: the surviving mosaic tilework displays, despite occasional lapses, an advanced capability in the planning and disposition of complex patterns and long inscriptions in and around complex spaces. And then there are the patterns and inscriptions, which themselves are not unique to this space. It is in integration of architectural form and space and tile decoration, rather than in novelty of motif and quotation, that they proclaim their mastery. ${ }^{\mathrm{I} 2}$

In what follows, I use images and description to portray the way in which writing is employed not only to draw attention to the dome and the îwan but also, through its interplay with the decoration and the architectural space, to advance different kinds and levels of understanding. As I proposed for the hadith around the doorway of the portal, I also argue that the writing's intended meaning unfolds not only in relationship to architectural space but also over the time spent by a frequenter of this building, another pedagogical and spiritual concern. The focus is on the decoration of the walls and dome of the central courtyard; however, the major 'eye-catching' device of the $\bar{\imath} w \bar{a} n$ - the inscription around its entrance arch and the accompanying raised band of reticulated ornament also mediates the transition between the $\bar{\imath} w \bar{a} n$ and the central space of the domed courtyard.

Over the centuries, the lower walls of this building have lost most of their tile decoration. However, from surviving examples, we can surmise that they were covered in their entirety with hexagonal tiles with monochrome turquoise glaze. 


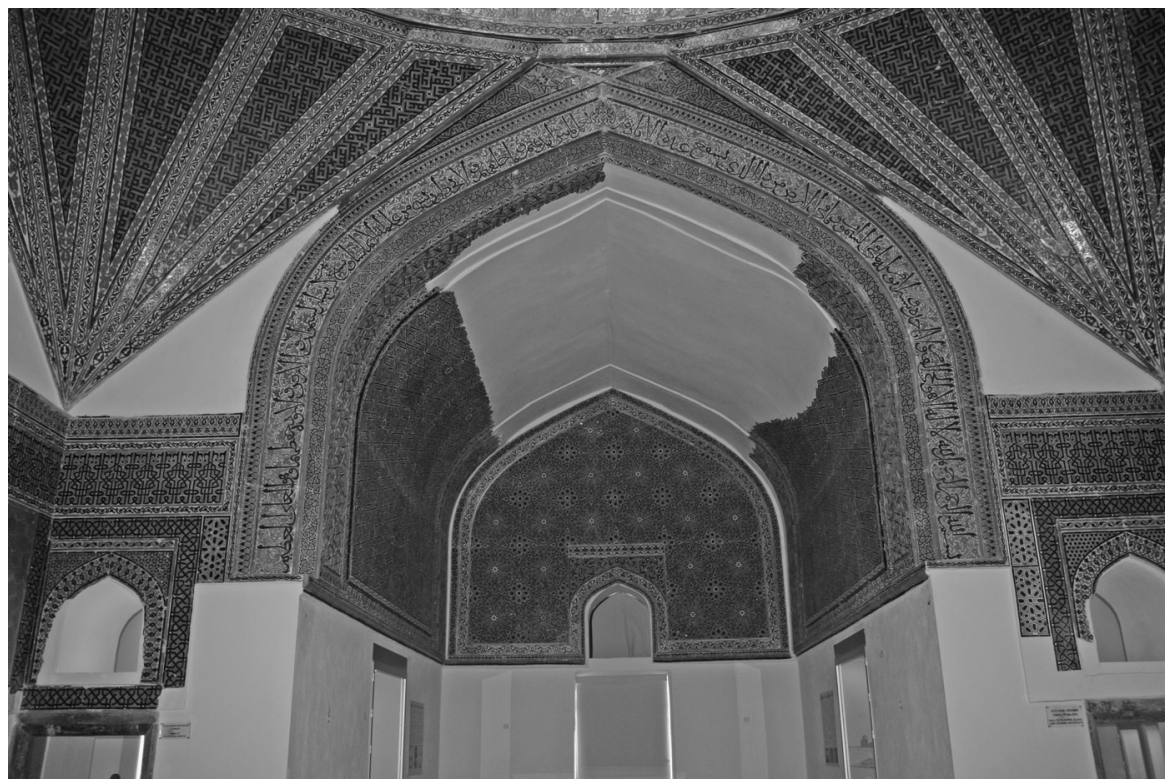

46. Qaratay Madrasa īwān, general view. (Photo: O. Eravşar)

The glazed surface of all surviving tiles is covered with stencilled gilded geometric and floral decoration, often featuring the six-pointed star known in Islamic cultures as the seal of Solomon. The only writing consists of the repetition of two phrases: al-'Izz lillāh, Glory to God, and al-Mulk lillāh, Sovereignty (alone) belongs to God. Both are commonly found on Seljuk and other medieval Islamic coins and inscriptions. The second phrase is used so often in Seljuk Anatolia that it is not outlandish to propose it as the religious motto, or one of the mottos or devices, used by the Seljuk sultans as a signature. The luxury of using gold-stencilled designs was confined to this lower level. All other tile decoration employs the tile mosaic technique.

Two inscriptions run above the level of this gilt-turquoise tile dado. Both are Qur'anic, and both were 'written' and designed in order to be read, with only slightly monumentalized Seljuk cursive writing in black standing out, plain and legible against a background of turquoise ornament scrolling against a white ground (Fig. 47). The inscription framing the entrance to the $\bar{\imath} w \bar{a} n$ from the courtyard is perhaps the most frequently found Qur'anic inscription in Islamic architecture, the Throne Verse (Sura of the Cow, verse 255), a central statement of Islamic faith.

This inscription frames the $\bar{i} w \bar{a} n$, at its top reaching almost to the base of the dome (Fig. 46). The introduction of the basmala at the beginning of the inscription allows the phrase about interceding with God (the verb is shaf'a) to hang at the very top of the arch. The placement of this phrase at the top of the arch constitutes one piece of evidence for intercession as one of the major themes of the epigraphic programme. Typical to the epigraphic programme of this building, the 
message is imported not by the choice of unusual and more pertinent Qur'anic passages, but by the visually, spatially and stylistically unusual and innovative ways in which common passages are displayed, as this example demonstrates.

Equally legible is another Qur'anic passage that tops the arches above the entrances to the rooms flanking the three sides of the courtyard. It reproduces other parts of the Sura of the Cow, verses 284-6 (Fig. 47).

In this architectural context, these verses may be interpreted in two ways. The first interpretation is a pedagogic one. Like the Throne Verse around the $\bar{\imath} w \bar{a} n$, they contain succinct and powerful statements about God, His omnipotence and His relationship with believers. On the walls of the Qaratay Madrasa courtyard, they are written in a clear, legible cursive hand, appropriate for apprehension by the students, and the writing stands out by virtue of its contrasting colour. Ornament scrolls as if behind the writing, but does not combine with it. Continuing as it does from door to door, this inscription visually unites the courtyard. A second possible interpretation emphasizes verse 285 , ties this inscription to those in the pendentives, and relates the mortal realm to that of the divine through God's messengers, prophets. This verse specifically mentions the validity of all prophets.

Between the Qur'anic quotation and the pendentives runs a band of decoration, one that at first looks like the style of writing - interlaced kufic encountered in the dome (Fig. 47). In this band, the interlace is prominent, but below it lie only three letter shapes that repeat themselves over and over. With the exception of the $\bar{\imath} w \bar{a} n$, this pseudo-epigraphic band runs all the way around the courtyard. The transition from the easily read cursive script of the gilded tiles and the Qur'anic verses to the knotted, angular kufic-style decoration is striking. Even though this band does not contain writing, its decoration (I) looks like writing, (2) is easily distinguishable as pseudo-writing and (3) marks a transition from cursive script to the use of kufic in all inscriptions above it.

Looking up, the next tile patterns encountered are massive triangular bands spreading between the four corners of the courtyard and the dome; one is pictured here (Fig. 48). This is a kind of fan pendentive known in art and architectural historical literature as a 'Turkish triangle' because of its use in Seljuk buildings in this era. Each of these triangular areas is divided into five thin triangular wedges separated one from the next by double bands of vegetal decoration. Like the interlaced pseudo-kufic band below it, the field of each triangle also contains angular patterns that resemble writing. On closer inspection, it is possible to puzzle out the repetition of single names within each triangular segment. With one exception, a single name occurs in each of the twenty segments (five to each triangle, four triangles, one at each corner of the courtyard) (Fig. 49).

Just as the Throne Verse running around the arch of the iwwan contributes to both the horizontal and vertical axes of movement of the building, so too these triangles contribute both a vertical and horizontal movement. The vertical axis is much more evident: starting from a point touching the top of the 


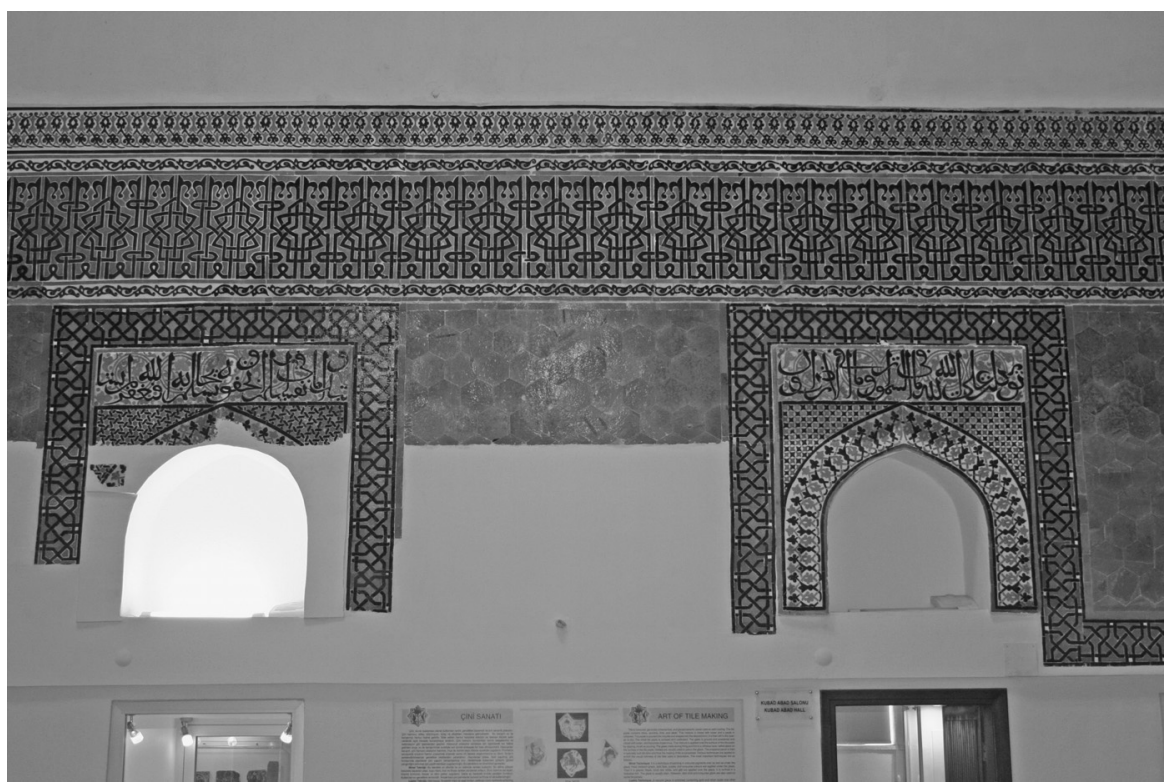

47. Qaratay Madrasa, general view of courtyard wall. (Photo: O. Eravşar)

pseudo-epigraphic frieze, these triangles fan out to the base of the dome to such an extent that they barely leave any stretch of wall uncovered there. As such, they contribute visually to the dominance of the dome, lifting the eye upwards toward it.

It is in their content, and not in their form, that these triangular fans impart a horizontal movement to the building. This axis of movement also relates to the temporal issue raised earlier, because it presents prophetic history, quite naturally in such a setting, from an Islamic point of view. This point of view is expressed within each single triangle, as well as in the overall scheme governing all four of the triangles.

As mentioned earlier, each of the triangles of the four fan pendentives has five segments. The name of the Prophet Muhammad is found in the central segment of each triangle. The four segments flanking this central segment seem to have been conceived temporally, with earlier prophets on the outermost pair, and later prophets, or Abu Bakr, the first of the Rightly Guided Caliphs (the four that succeeded Muhammad after his death) filling the inner pair. As the diagram reproduced in Fig. 49 shows, on the southeast triangle (that above the entrance), Muhammad's name is flanked by those of Jesus and Abu Bakr, whereas on the outermost segments, Moses is to one side and, likely due to error, Jesus and Abu Bakr, exceptionally, share the same segment. The northeastern triangle is clearer: the name of Muhammad is flanked by those of Jesus and Abu Bakr, with the names David and Moses on the other segments to either side of them.

As we have seen, the temporal succession (or completion) of Abrahamic prophets by the Prophet Muhammad then continues with caliphs. On the two triangles 


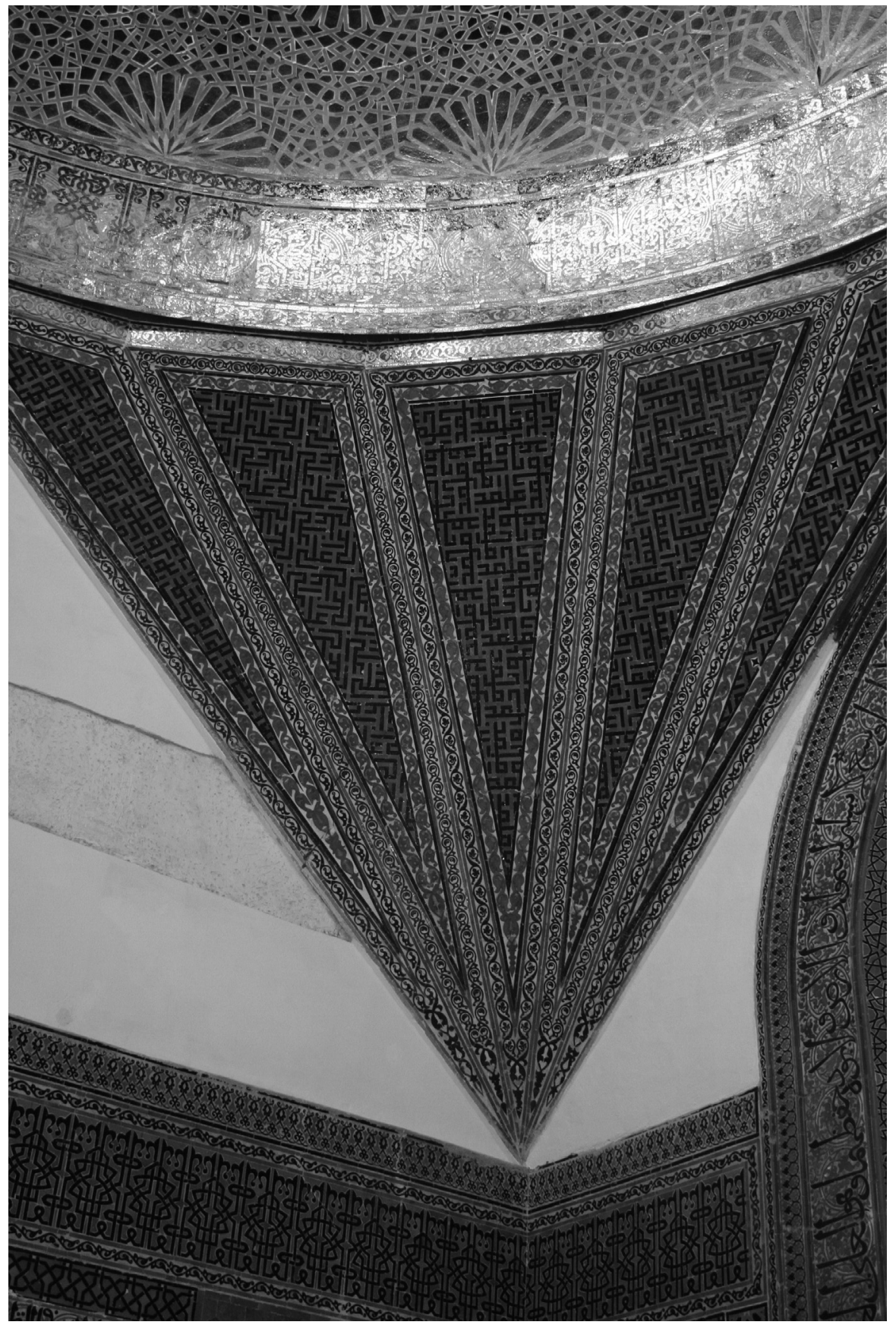

48. Qaratay Madrasa, southwestern 'Turkish triangle'. (Photo: O. Eravşar)

to the east, or back of the courtyard, only the name of the first of the Rightly Guided Caliphs, Abu Bakr, is present. On the western triangles, he is 'succeeded' by the other three Rightly Guided Caliphs: 'Umar, 'Ali and 'Uthman. In both the north-west and south-west triangles, the name of Muhammad is flanked by 

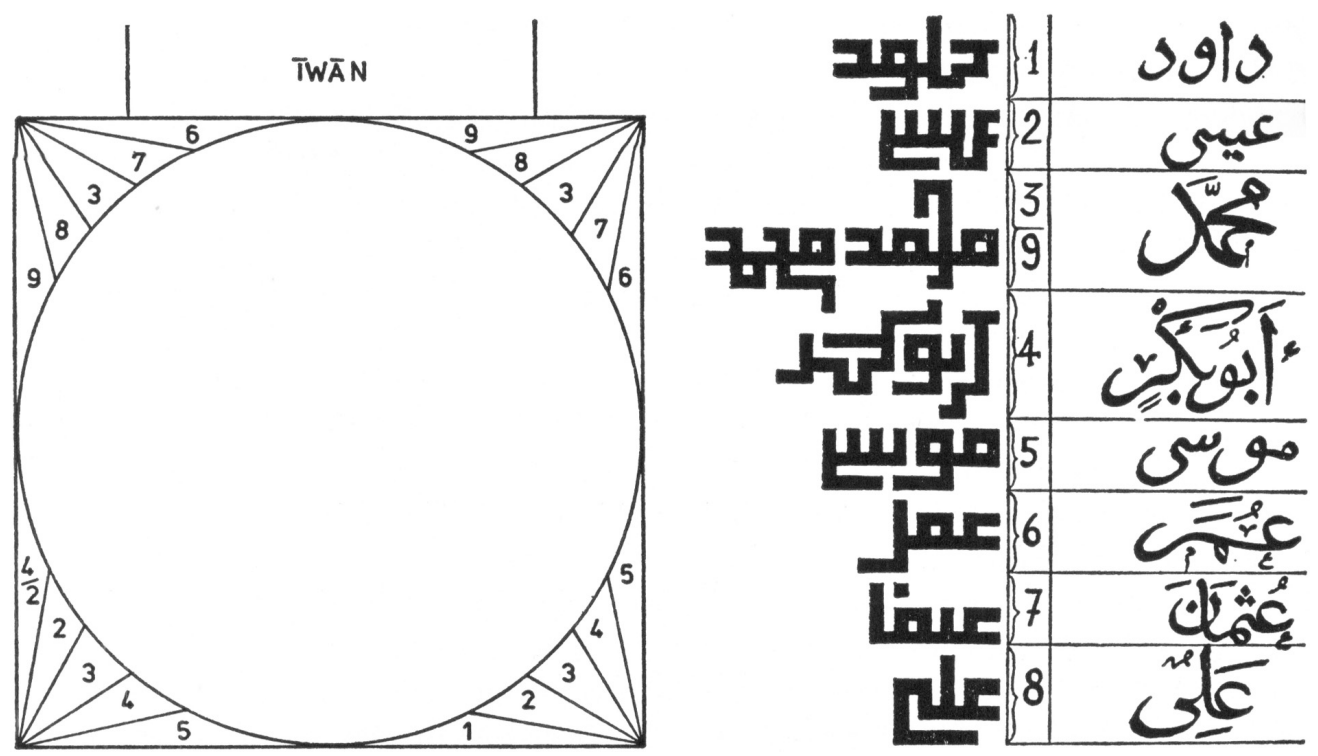

49. Qaratay Madrasa, diagram showing the arrangement of the prophetic and caliphal names in the segments of the Turkish triangles. (After Michael Meinecke, Fayencedekorationen seldschukischer Sakralbauten in Kleinasien [Tübingen: Ernst Wasmuth, 1976], Volume 2, Illustration

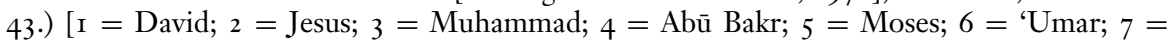
'Uthmān; $8=$ 'Alī'; $9=$ Muhammad]

segments bearing the names of 'Ali and 'Uthman. However, in these two triangles, the succession seems to be intended to be read both centrally and sequentially from right to left, with the second Caliph 'Umar followed by the 'Uthman, and then, after Muhammad in the central segment, 'Ali. This leaves one final segment with no more Rightly Guided Caliphs, so it is filled in once again with the name of Muhammad.

Earlier I referred to the association of the thirteenth-century Konya-based copyist/illustrator of the eleventh-century Persian romance of Varqeh and Golshah with the social milieu of Jalal al-Din Qaratay, as testified by his serving as a witness to the foundation document of his madrasa. Given the prominence and placement of the name of the Prophet Muhammad in this building, it is interesting to note the prominent intercessory role played by Muhammad in the poem. Moreover, although they are not mentioned in the text, in this romance the four men who were to become the Rightly Guided Caliphs are illustrated seated together with Muhammad himself. Priscilla Soucek has noted that this is the first surviving instance of figural representation of the Prophet Muhammad together with these of his companions, a subject that she notes finds increased favour later in the thirteenth century and into the fourteenth century in Islamic manuscript painting. The particular miniature in the manuscript of Varqeh and Golshāh that represents the Prophet together with these four of his companions introduces the king of Syria into the scene, necessitating the removal of all four of 
these figures to one side of the centrally located figure of Muhammad. However, later representations portray, as is represented onomastically in the fan pendentives of the Qaratay Madrasa, Muhammad in the middle, flanked by 'Ali, 'Uthman, Abu Bakr and 'Umar. ${ }^{13}$

The temporal succession of prophets and caliphs has its own internal order within each triangle, even though that order was not strictly followed. What is clear, however, from the absence of the names of David, Moses and Jesus from the two triangles flanking the $\bar{\imath} w \bar{a} n$ to the west of the building is that the succession of prophetic and caliphal names proposes a horizontal movement parallel to the movement of the visitor/student/teacher to the school, from entrance to $\bar{\imath} w \bar{a} n$. To the temporal element of prophetic and caliph succession across the space of the courtyard can be compared the time it would take a student living and studying in the building to puzzle out the intricate, interlocking kufic names of each segment, put them together in individual sequences within each triangle and arrive at the overall idea underlying this major element of the decorative programme. The world of scholarship continues to use the key first published by Mehmet Önder in 1962 (Fig. 49). What if a student studying here had no such crib? The decorative programme is meant to be revealed through mental application over time, as the eye strays from the $\bar{i} w \bar{a} n$ and the mind strays from the sound of the lesson passing from the $\bar{i} w \bar{a} n$ and reverberating through the domed space of the courtyard.

The tile mosaic decoration of the interior of the hemispherical dome of the Qaratay Madrasa is one of the best-known works of Anatolian Seljuk art. The reticulated patterns found in subsidiary parts of the building, on the façade, and flanking doorways and inscriptions resolve here into a web more complex than the hexagon-centred patterns below, spinning a series of webs that contain four rows of sixteen centriform, segmented stellate forms (Fig. 50). These forms, which emerge from and disappear into the edges of the design field, become smaller and get closer to one another as they approach the oculus at the top of the dome.

Bordering this extraordinary field, which has been likened to everything from a field of daisies to whirling dervishes, are two more panels of writing to its top and bottom. Like the writing below, they both play on the border between pattern and writing. The reward behind the dare implicit in the complexity of the knotted patterning and distorted letterforms of the knotted interlace kufic of the lower inscription lies in the recognition of a Qur'anic passage reproduced below in a much more legible form: the Throne Verse (Fig. 50). Once again, a temporal element is built into the decorative programme - perhaps the understanding gained by extended exposure to this inscription would give more profound insight to the student than the verity that may have accompanied the easier reading of the same famous Qur'anic passage given closer to the level of human use of the space below in legible cursive script. 


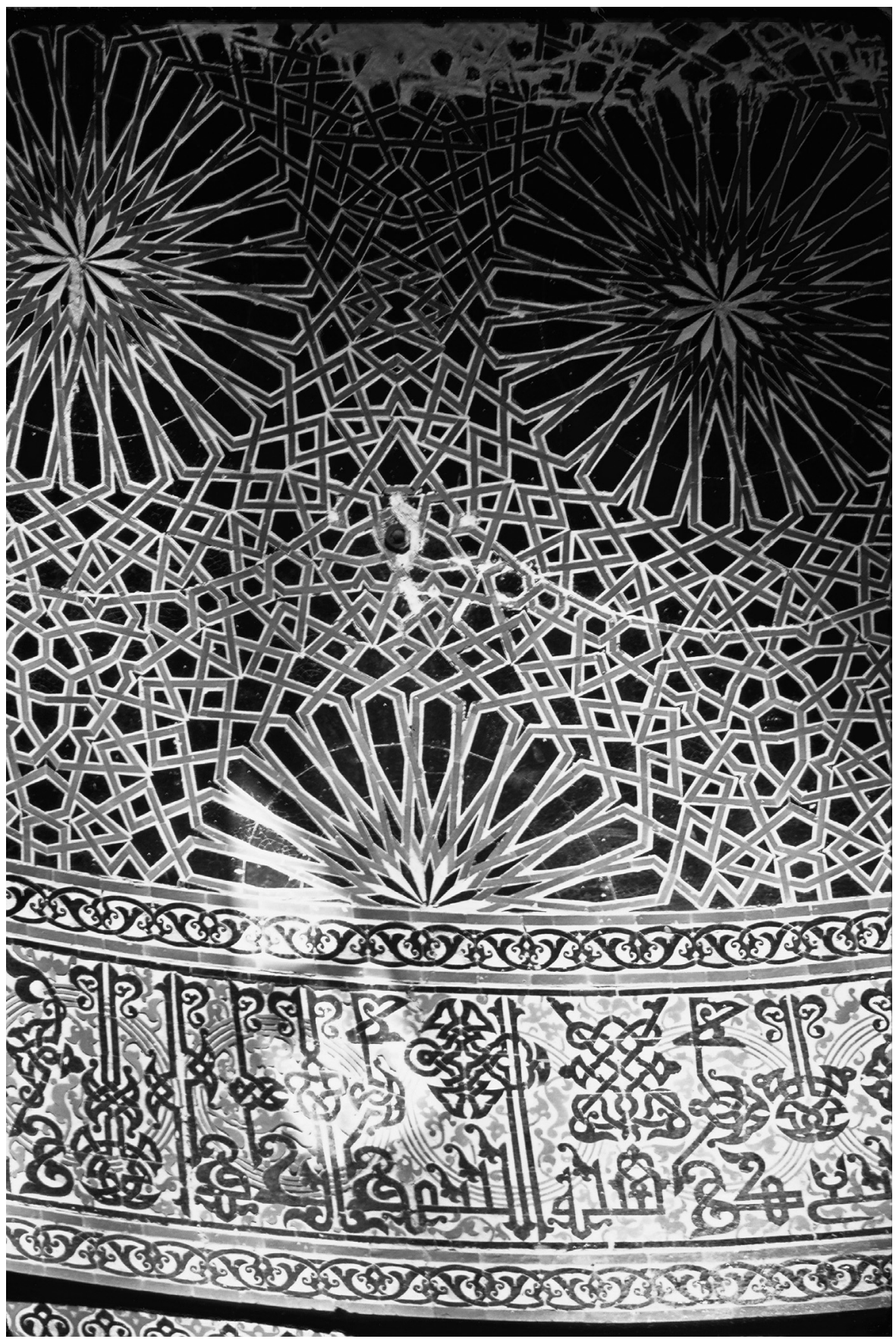

50. Qaratay Madrasa detail of the inscription at the base of the dome. (Photo: S. Redford) 
Just as the stellate forms in the tile mosaic decoration of the dome grow smaller as they approach the oculus, so, too, does the writing on the upper band, immediately below the oculus, diminish in size, thereby increasing the difficulty of decipherment. However, the shapes of the letters are less distorted, and there is less knotting and interlace, leading to a quicker understanding that this band, too, reproduces the Throne Verse.

There is one addition to both of these bands that is not found in its cursive iteration below: the subsequent verse, no. 256 :

There is no compulsion in religion. The right direction is henceforth distinct from error. And he who rejecteth false deities and believeth in God hath grasped a firm handhold which will never break. ${ }^{\mathrm{I}}$

I leave it to the reader to decide whether this addition can be related to the unusual inclusion of a Qur'anic inscription giving voice to Solomon on the portal and of the names of David, Moses and Jesus on the interior, or whether it simply fills the added space available in the dome.

\section{DISCUSSION AND CONCLUSION}

The attentive reader may have surmised a connection between the tilework, the spiritual predilections of the patron who paid lavishly for it and the general outlines of the structure of the attainment of spiritual knowledge. The thesis proposed here is based on a correspondence between mystic ideas of divinity, knowledge and truth; both literal and figural enlightenment and reflection; and levels of knowledge. The meaning that the tile programme aimed to impart was based both on the content of the inscriptions (especially the Qur'anic inscriptions, which are the most common) and on their placement and style.

To summarize: at the bottom, at eye level, we begin with gilded inscriptions - themselves declaring the power of God, but recognisable as mottoes used in imperial/sultanic contexts. They are mixed, however, with decoration that implies some sort of esoteric knowledge, a clue, if you will. The next level contains inscriptions (both around the arch of the $\bar{\imath} w \bar{a} n$ and above the entrances to the rooms around the other three sides of the courtyard) that are at the same time forceful, clear and well-known Qur'anic statements of the power of God. Immediately above this level, in the courtyard, is a layer of obfuscation: writing that is not writing, but is easy to recognise as such. It introduces the angular form of writing known as kufic, which was not usually used at the time; however, when used, it was often associated with esoteric knowledge. Therefore it could also be thought of as demarcating a boundary, in the way pseudo-kufic decoration would have been used on a contemporaneous carpet. Above this layer is the opposite: kufic writing that looks like decoration, but is not. This writing consists of names of prophets and caliphs. Ascending, as they are, they can be viewed as being in an 
intercessory position between the human and the divine, but the arrangement of names also argues for a temporal progression from Abrahamic prophets through Muhammad to the Rightly Guided Caliphs. These names literally fan out to the base of the dome, on which the Throne Verse is written twice, at its base and its top, at the opening of the oculus. In both instances it is written in kufic, first in an almost impossibly beautiful and difficult way and then in a more comprehensible one.

Above this is the open sky, main source of light for the building. Passing through the oculus, light circles through the courtyard as the day progresses, literally enlightening parts of the decoration, the writing and all that is in between (Fig. 50). At the same time, the light reflects in the pool directly below the oculus, diffusing in a more indirect way and subtly distorted by the gradual flow of water through it. Enlightenment and reflection - two processes that take time - are presented together to those studying in the ivwan of the madrasa as daily facts, but the increasing complexity of the decoration/writing as the tile programme ascends invites, even demands, the passage of time (and the lifting of one's head from books, or one's gaze from the teacher). The passage of time implicit in the movement from the doorway into the covered courtyard to the main place of instruction, the $\bar{\imath} w \bar{a} n$, is paralleled by the movement of progression of prophetic time, from the other Abrahamic religions to Islam (even as Muhammad, the prophet who ushered in the return to the original faith of Abraham, is omnipresent). The levels of inscriptional and pseudo-inscriptional tilework that culminate in the oculus of the dome are structured in a way analogous to the levels (manzil, pl. manāzil) of knowledge of God attainable through study.

Muhammad had a prominent role in Islam, mystical or not, as an intercessor, so his prominence in the inscriptional programme of the fan pendentives comes as no surprise. Muhammed can also be related to the idea of enlightenment through the widespread belief in his luminous quality, the light of Muhammad, nür alMubammad; this concept was found in the writings of mystics present in Anatolia - Rumi, Ibn 'Arabi and Yunus Emre - at about this time. Thus, the inscriptional programme invites us to think of him as both intercessor for Muslims and as the possessor of a divine light that can lead the Muslim student toward enlightenment. Both aspects of Muhammad also link him to the celebration here of events connected with his life at night, which are illuminated with candles that are prescribed in the building's foundation document. Even though the placement of Muhammad's name encourages such an interpretation, it must be noted that the formulators of the epigraphic programme did not use badith or different Qur'anic passages associating Muhammad with both light and with intercession. Yet this absence of such writings is congruent with the general avoidance of explicit statements here and the use of placement, programme and epigraphic style as clues to meaning. According to Islamic belief, Muhammad intercedes with God on behalf of believers on Judgement Day. In this sense, the prominence of intercession as a theme of the inscriptional programme of the Qaratay Madrasa can 
be thought of as chosen for a structure that houses the tomb of its patron, who was advanced in age when it was being built, and died soon after its completion. ${ }^{15}$

Earlier in the chapter I used the term 'axis' in a standard art-historical way to describe the organization of space, movement, decoration and light in the interior of the Qaratay Madrasa. This word can be used in another way, as in the term axis mundi, which is one way to translate the word qutb. This word is a common one in medieval Sufi writings used to describe a saint, a holy man, teacher or one with special spiritual insight. This word, which can also be a title, is not used anywhere in the inscriptional programme of the Qaratay Madrasa. Rather, it is used twice in the foundation document of the building. On the façade of the Qaratay Madrasa, the foundation inscription gives the reigning sultan only two titles, both standard issue: 'the Greatest Sultan' and 'Shadow of God in the World'. The same inscription mentions Jalal al-Din Qaratay without giving him a title, although his high status is implied by the absence of any version of the phrase, 'the humble servant in need of the mercy of God', which usually precedes the names of emirs in Seljuk inscriptions.

In a manner similar to Seljuk foundation inscriptions, the foundation document of the Qaratay Madrasa is organised in descending order. It begins with praise for God; followed by praise for the caliph in Baghdad; then praise, names and titles for the Seljuk Sultan ('Izz al-Din); and finally for Qaratay himself. In the way that Sufism at the time used temporal terminology and titles for religious people, in the last section of this document, Jalal al-Din Qaratay refers to himself, among other 'titles', as 'Lord of the Ascetics, Axis (qutb) of the Believers, Master of the Emirs and the Saints, Helper of the People, Source of Blessings, Cream of the Times, Exemplar of the Saints (awliya - plural of wali ) Crown of the Sufis' ${ }^{16}$ In the foundation document of his caravanserai, Qaratay refers to himself as, among other things, 'King of the Sufis (abdāl)' and 'Axis (qutb) of the Ascetics' ${ }^{17}$

These and (many) other titles and names given in the foundation documents are congruent with the depiction of Jalal al-Din Qaratay as a pious Muslim with mystical inclinations. The title $q u t b$ is of particular interest: Franklin Lewis informs us that, in the writings of Jalal al-Din Rumi, the prophets, saints and caliphs who were quțb (pl. aqtāab) included David, Solomon, Moses, Jesus and Muhammad, followed by the Rightly Guided Caliphs: in short all of those named or referred to in the inscriptional programme of the madrasa itself. Ibn Bibi writes that Jalal al-Din Qaratay was possessed of the spirit of Suhayb (a companion of the Prophet known for his abstemiousness) and with knowledge of the esoteric (asrār-e ghayb). Still, despite shared nomenclature, a spiritual gap exists between saints and prophets. ${ }^{18}$

In a manner similar to the Sunni orthodoxy of the inscriptional programme, the foundation document does not mention mystical instruction, but rather prescribes that Sunni orthodox Islamic theology and law of the Hanafi school were to be taught here. The main teacher (mudarris) was to be from this legal school, 
although imams from the three other Sunni schools of law were also permitted. Instruction was in $u s \underline{u} l$ and fur $\bar{u}$ ' as found in madrasas across the Islamic world at this time. This prescription is one reason that $\mathrm{I}$ have emphasized the patron and not the curriculum of instruction as a driving force behind the decorative and epigraphic programme. ${ }^{19}$

A cottage industry of writers and publishers has regularly imparted religious, especially mystical, meaning to works of Islamic art and architecture. The subject of mystical interpretation of a work of Islamic architecture, therefore, is a sensitive one, not only because it is hard to prove but also because maintaining that artistic traditions exist mainly to embody eternal religious verities opens one up to charges of cultural essentialism. ${ }^{20}$ In finding analogies between the neoplatonic structures of Sufi thought, with their levels of meaning, and the levels of ornament and writing in the domed courtyard of the Qaratay madrasa, I hope to have grounded my argument securely enough in the cultural circumstances of mid-thirteenth century Konya and the person of Jalal al-Din Qaratay to avoid these charges.

In closing, I return to an issue raised at the beginning of this chapter, and that is the relationship of Christianity to Islam. This is an important issue, personally for a convert such as Jalal al-Din Qaratay and generally in medieval Anatolia, a land that had been predominantly Christian for centuries and one that still, at this time, must have had a population that was majority Christian. The 1202 foundation document of the Altun Aba Madrasa in Konya prescribes the use of candles on the three holy nights mentioned earlier. The I 280 Sivas Gök Medrese foundation document stipulates that candles be lighted during prayers as well as mealtimes on these nights. Together with the foundation documents of Qaratay, these documents cover almost the entire thirteenth century and therefore can be seen as representative of Islamic religious practice in Anatolia then: not a cryptoChristian practice prescribed by one man, but an association of candlelight with faith common with Christian practice in this place and time. ${ }^{2 \mathrm{I}}$ The prescription of the use of candles in two buildings built and endowed by Jalal al-Din Qaratay participates in this trend; wittingly or unwittingly there is a continuity of praxis between these two religions. Is there anything else here that bridges these religious and cultural traditions?

The domed madrasa is a feature of medieval Anatolian Islamic architecture and as such is not found elsewhere in the Islamic world. The number of domed madrasas in Anatolia dating to the twelfth and thirteenth centuries is small in comparison to those with open courtyards. In the context of traditions of religious architecture, it is, on the surface, easy to think about the domed madrasa as a form influenced by Byzantine ecclesiastical architecture until one sees its single hemispheric dome, so different in shape and size from Byzantine, Armenian or Georgian domed churches of the time. ${ }^{22}$

The Qaratay Madrasa is the first of a series of domed madrasas with such domes and without columnar support, a series that begins in the 1250 and continues 
for more than thirty years. Therefore, it can be considered an important index not only of a regional tradition but also of its revival and modification, and the question of intent lies behind the choice of this building type. The placement of the names of prophets and caliphs in the pendentives and the sense of the progression between them, although not paralleling Byzantine or other Christian practice, seem to be beholden to it in some measure. This is also the case with the twin foci on the $\bar{\imath} w \bar{a} n$ and the dome and with the hierarchical presentation of sacred space. However, rather than an instance of cultural borrowing, perhaps one can see this practice as another instance of the creation of a distinctly Islamic space that contains Christianity within it, in the way that Islam acknowledges Jesus as a prophet. ${ }^{23}$

This sense of progression from Christianity to Islam can also be seen in the tomb chamber of Qaratay within his madrasa. Its dome is devoid of decoration, in stark contrast to the dome of the courtyard. Almost nothing remains of its inscriptional programme except part of the same tile dado with a gilded inscription and part of a Qur'anic inscription in the same legible cursive hand, part of a sura (The Troops, verse 9) found on the wall. This sura is concerned with death and the afterlife, and therefore appropriate to the funereal nature of this space. The verse that originally was reproduced in full on the walls of the tomb chamber, however, is concerned not only with an interest in the afterlife but also with the difference in knowing (the truth) between (Muslim) believers and unbelievers, a condition that also bears on Qaratay's own passage from Christianity to Islam.

Remarkably, the door frame of the entrance into the tomb chamber from the courtyard is made up of architectural sculpture that has been recognisably reused from a Byzantine church, the only piece of spolia obviously employed in this building. This could be seen as another, different means of referencing Christianity as prefatory to the truths of Islam: to enter the tomb chamber, one has to pass through a doorway recalling a Christian church. In a similar fashion, the Qur'anic inscription on the portal anticipates the progression of prophetic and historical time elaborated on the Turkish triangles of the interior.

The Qaratay Madrasa appears to be the first surviving Islamic building whose epigraphic programme places the names of important caliphs and prophets in high places, especially around the base of the dome - a practice that became widespread in religious architecture in later centuries. However, there are other buildings in Anatolia, both earlier and later than this building, that also have inscriptions placing the name of Muhammad in high places. These inscriptions are more prosaic (and more legible, too!). The earliest surviving example seems to be the placement of the name of Muhammad in star form at the top of a dome of the Ulu Cami at Malatya, which has been dated to I 224. The names of Allah and Muhammad are placed at the base of the minarets of the Çifte Minareli Medrese in Erzurum, undated but from about this time period, and in the Sahib Ata complex in Konya, dated I 258. The Tahir and Zühre mosque in Konya, 
also undated by inscription, but belonging to the late thirteenth century, bears, on the crown of the dome, tile mosaic decoration, which is also in star form, with the names of Muhammad and the Rightly Guided Caliphs. These examples illustrate not only similar concerns at the time but also a less developed decorative programme. $^{24}$

The Qaratay Madrasa uses changes in level and in script style and difficulty to invoke the secrecy and mystification of divine knowledge. Doing so did exclude from understanding both the 'literate and illiterate' who benefitted from Jalal alDin Qaratay's generosity, but not the teachers and students who lived and worked in the Qaratay Madrasa and had its secrets revealed to them gradually, through literal and metaphorical reflection and illumination. Jalal al-Din Qaratay can be seen as playing a dual intercessory role: as a patron in building the building, but also as a saintly man, as God's friend on earth revealing through his actions knowledge of God to others, just as did the prophets and caliphs in the past. In turn, he relied on the Prophet Muhammad to intercede with God on his behalf on Judgement Day.

\section{NOTES}

I. The fourth chapter of Sara Nur Yildiz, Mongol Rule in Seljuk Anatolia: the Politics of Conquest and History Writing I243-I282 (Brill: Leiden, in press) gives a lucid account of the politics of the period of regency.

2. Bar Hebraeus, E. A. Wallis Budge trans., The Chronography of Gregory Abu'l Faraj (Piscataway, NJ, 2003 (reprint of 1932 Oxford University Press edition)), I: 4I3 'And there was in Kanya (sic) a certain noble, an old slave of Sultan Ala ad-Din, whose name was Jalal alDin Karatai (sic), and he was an ascetic who abstained from the eating of flesh, and from the drinking of wine, and from women, and he was a good and merciful man.' See also Ibn Bibi, El-Evamirü'l-Ala'iyye fi'l-Umuri'l'Ala'iyye (Ankara, I956), 593-4, and Franklin Lewis, Rumi Past and Present, East and West (Oxford, 2000), 278-9.

3. See Osman Turan, 'Celaleddin Karatay, Vakıfları ve Vakfiyeleri,' Belleten 47 (I948), I32 for the relevant passage concerning the madrasa; 95-6 for that in the waqfiyya (endowment/foundation document) of the caravanserai. The same prescription is given in the waqfiyya of his brother's madrasa across the street and in the later (I280) waqfiyya of the Gök Medrese, built in Sivas in I $27 \mathrm{I}$ by Sahib Ata, an emir of nonslave origin; see Sadi Bayram and Ahmet Hamdi Karabacak, 'Sahib Ata Fahrü'd-Din Ali'nin Konya, İmaret ve Sivas Gökmedrese Vakfiyeleri,'
Vakıflar Dergisi I 3 (I98I), 56. In all of these documents, the sacred nights are referred to only by their dates.

4. Ibn Bibi, El-Evamirü'l-Ala'iyye, 593; Turan, 'Celaleddin Karatay,' 47-9 on the brothers mentioned in the waqfiyyas; Ibrahim Hakkı Konyalı, Konya Taribi (Konya, I964), 875 for the theory that he was from Konya, and Michael Meinecke, Fayencedekorationen seldschukischer Sakralbauten in Kleinasien (Tübingen, I976), Vol. 2, 278-83, for the remains of the building, which interestingly was not domed.

5. See, for instance, Robert Jordan (trans.), 'Pantokrator. Typikon of Emperor John II Komnenos for the Monastery of Christ Pantokrator in Constantinople' in eds. John Thomas and Angela Constantinides Hero, Byzantine Monastic Foundation Documents (Washington, D.C., 2000), 740-3 for the burning of oil lamps in the church, including all night, although it is specified that candles burn in the most important parts of the church, in front of important icons and during important feast days.

6. See Ibn Bibi, El-Evamirü'l-Ala'iyye, 569; also Marion Holmes Katz, The Birth of the Prophet Muhammad. Devotional Piety in Sunni Islam (London: Routledge, 2007), 50-62 for the emergence of a genre of texts relating to the Prophet's birth in the twelfth century in Iran and Iraq and the emergence of Sunni 
celebrations of it, and $147-68$ for notions of homogeneous and nonhomogeneous time in Islam in relation to the merits of certain days such as the birth of the Prophet. See Assadullah Souren Melikian-Chirvani, 'Le roman de Varqe et Golsah: Essai sur les rapports de l'esthétique littéraire et de l'esthétique plastique dans l'Iran pré-mongol, suivi de la traduction du poème,' Arts asiatiques 22 (I970), which gives a French translation of the text of Ayyūqī's Varqeb o Golshāh, with the climactic episode of prayer and resurrection found in verses 2 I 68-22 24. On page I 3, Melikian-Chirvani concludes, following Ahmed Ateş, 'Un vieux poème romanesque persan: récit de Warqah et Gulshah,' Ars Orientalis 4 (I96I), I46-7, that the composition of this work likely dates to the reign of Ghaznavid Sultan Mahmūd (d. IO3O), based on the language of the text and the mention of titles congruent with those of this sultan. M. Kemal Özergin, 'Selçuklu Sanatçısı Nakkaş Abdül-Mu'min el-Hoyi Hakkında,' Belleten 34 (I970), 227, made the connection between the artist who signed this manuscript and the name on the Qaratay endowment document.

7. Meinecke, Fayencedekorationen, 2: 298 and Meinecke, 'Tuslu Mimar Osman Oğlu Mehmed Oğlu Mehmed ve Konya'da I 3.üncü Yüzyılda bir Çini Atölyesi,' Türk Etnografya Dergisi I I ( I968), 8 I-93.

8. The inscription dates to the period of Qaratay's regency for three brothers. Although quite naturally the inscription should have mentioned 'Izz al-Din, the only one of the brothers then holding the title of sultan, it does not. Rather, it bears the name of his brother 'Ala' al-Din. The block of stone that should mention this brother is the only one of the ten blocks of marble that form this inscription not to have a double, but a single line of writing. Doubts about its originality are not limited to its format: the next panel refers to the latter part of 'Ala' al-Din's name as Kayka'us, which is the latter part of the name of his brother 'Izz al-Din, and not Kayqubadh as it rightly should be. The only brother mentioned in the waqfiyya as sul$\tan$ is 'Izz al-Din, so it is obvious that this inscription has been tampered with and (partially) changed to the name of his youngest brother. Other problems concern the choice of the content: the genealogy of the inscription is much longer than usual, but there is no caliphal title. Qaratay's name is mentioned, but without title, whereas the inscription, unusually, has a benediction for him, but not for the sultan.

9. Mehmet Eminoğlu, Karatay Medresesi Yazı Incileri (Konya, n.d.), I6-4I. See Konyalı, Konya Taribi 847 and Eminoğlu, Karatay Medresesi $\mathrm{I} 5-4 \mathrm{I}$ for hadith collections that could have been consulted for these wellknown sayings of the Prophet.

ıо. Eminoğlu, Karatay Medresesi ı, without demonstrating how he arrives at this conclusion, writes that this abstract geometric patterning actually is a symmetric pairing of the words 'Allah' and 'Muhammad'.

I I. Aptullah Kuran, Anadolu Medreseleri (Ankara, I969), 5 I-2, considers this to have been a domed space, whereas Meinecke, Fayencedekorationen Vol. 2, 287, proposes a segmented dome.

I2. Earlier, I discussed the relationship between the façade of this building and that of the Alaeddin mosque. Because of this connection, and because it is likely that the same workshop executed the tile mosaic here and, twenty years earlier, of the mibrab and dome of the Alaeddin mosque, this tile program could be seen as an elaboration or reworking of the program there. Unfortunately, little remains of the earlier programme the heart of the mibrab was replaced in the nineteenth century, and the dome has lost its tile decoration, so any possible connection between the two tile programs remains impossible to explore in any sustained way.

I3. Priscilla Soucek, 'The Life of the Prophet: Illustrated Versions,' in Content and Context of Visual Arts in the Islamic World, ed. Priscilla Soucek (University Park, I988), I94.

I4. Mohammed Marmaduke Pickthall (trans.), The Meaning of the Glorious Koran (New York: Mentor, n.d.). I modified this translation only by substituting 'God' for 'Allah'.

I 5. Annemarie Schimmel, And Mubammad Is His Messenger. The Veneration of the Prophet in Islamic Piety (Chapel Hill, I 985), 83-4 for his role as intercessor, $123-30$ for the light of Muhammad, I 27 for Ibn 'Arabi's promotion of the idea of the light of Muhammad, and I 34 for Ibn 'Arabi's idea of Muhammad as 'the suture between the Divine and the created world' and 'the isthmus between the Necessary and contingent existence'.

ı6. Turan, 'Celaleddin Karatay,' г 30.

I 7. Ibid., 9I.

I8. Ibn Bibi, El-Evamirü'l-Ala'iyye, 593-4; Lewis, Rumi, 4Io.

I9. Turan 'Celaleddin Karatay,' I 2 2-3. 
20. For a critique of a strand of Islamic art history that finds unchanging religious and mystical meaning in decoration, see Gülru Necipoğlu, The Topkapi Scroll - Geometry and Ornament in Islamic Architecture (Los Angeles, I995), $73-83$.

2 I. Osman Turan, 'Şemseddin Altun-Aba, Vakfiyyesi ve Hayat1,' Belleten I I (I947), 2 29; Sadi Bayram and Ahmet Hamdi Karabacak, 'Sahib Ata Fahrü'd-Din Ali'nin Konya, İmaret ve Sivas Gökmedrese Vakfiyeleri,' Vakıflar Dergisi I 3 (I981), 56.

22. Robert Hillenbrand, Islamic Architecture. Form, Function, and Meaning (New York, I994), 2 IO, notes that of fifty-three madrasas surviving from medieval Anatolia, only fifteen are domed. On pp. 2 IO-I 2, he discusses possible reasons - climatic, compositional and cultural - for the phenomenon of the domed madrasa. In considering the matter of overlap with Christian traditions he has the following to say: 'First, the compact madrasa with large central dome and smaller domed or vaulted areas surrounding it cannot fail to recall the standard type of mid-Byzantine church, which was widespread in Anatolia at the time of the Turkish conquest. Nor is this resemblance simply a matter of external silhouette; the rear îwān flanked by dome chambers in the domical madrasas of Konya brings to mind a Byzantine church apse flanked by diaconicon and protbesis.' Kuran, Anadolu Medreseleri, 8-9, finds the origin of the domed courtyard madrasa in pre-Islamic Central Asian domestic architecture and the origin of the open-courtyard madrasa in Buddhist monasteries.

23. See Kuran, Anadolu Medreseleri, 62-3, for the subgroup of domed madrasas erected beginning with this building.

24. Meinecke, Fayencedekorationen, 2: I4I, for the Cifte Minareli Medrese in Erzurum, 308 for the Sahib Ata complex in Konya (1258). There are similar roundels at the bases of the minarets of the Gök Medrese (I 27 I) and Çifte Minareli Medrese (I27 I2) in Sivas that also likely once contained these names; unfortunately these roundels are now empty. For the Tahir and Zühre mosque in Konya see Rüçhan Arık and Oluş Arık, Tiles. Treasures of Anatolian Soil. Tiles of the Seljuk and Beylik Periods (Istanbul, 2008), I 5 I, fig. Io9 and Meinecke, Fayencedekorationen, 2: 360 . 